\title{
Sistem Pendukung Keputusan \\ Penentuan Peminatan Peserta Didik Menggunakan Metode Weighted Product Berbasis Web (Studi Kasus : SMA Negeri 1 Purwodadi Grobogan)
}

\section{Gigih Adi Prabowo dan Beta Noranita}

Jurusan Ilmu Komputer/Informatika

Fakultas Sains dan Matematika Universitas Diponegoro

Jl. Prof. Soedarto, S.H, Tembalang Semarang - 50275

Email : gigihadip.if@gmail.com

\begin{abstract}
Abstrak
Peminatan peserta didik adalah suatu pembelajaran berbasis minat peserta didik sesuai kesempatan belajar yang ada dalam satuan pendidikan. Penyelenggaraan pendidikan dalam satuan pendidikan di SMA berdasarkan kurikulum 2013 terdapat program penentuan peminatan bagi peserta didik SMA yang dilaksanakan di kelas X. Peminatan dalam kurikulum 2013 di SMA adalah kelompok peminatan Matematika dan Ilmu Alam (MIA) dan peminatan Ilmu-Ilmu Sosial (IIS). Adapun kriteria dalam peminatan seperti nilai ujian nasional, prestasi non akademik, psikotes, dan minat. Proses peminatan yang dilakukan oleh guru BK dengan membandingkan nilai siswa yang satu dengan yang lain dinilai tidak efektif dan tidak efisien. Sistem Pendukung Keputusan Penentuan Peminatan Peserta Didik membantu guru BK dalam menentukan minat peserta didik. Sistem ini dibangun dengan menggunakan metode Weighted Product karena metode ini mampu menghasilkan minat dengan nilai tertinggi dibandingkan nilai minat yang lain. Hasil penentuan peminatan yang dilakukan oleh sistem menghasilkan tingkat akurasi sebesar $85 \%$ yang didapatkan dari pengujian 100 data siswa calon penerimaan tahun 2014.
\end{abstract}

Kata kunci :Sistem Pendukung Keputusan, Weighted Product, Penentuan Peminatan

\section{Pendahuluan}

Pengembangan Kurikulum 2013 dimaksudkan untuk meningkatkan mutu pendidikan dan didalamnya terdapat perubahan program yang berkaitan langsung dengan layanan bimbingan dan konseling adalah peminatan peserta didik. Peminatan peserta didik merupakan suatu proses pengambilan pilihan dan keputusan oleh peserta didik dalam bidang keahlian yang didasarkan atas pemahaman potensi diri dan peluang yang ada [5].

Penyelenggaraan pendidikan dalam satuan pendidikan di SMA berdasarkan kurikulum 2013 terdapat program penentuan peminatan bagi peserta didik SMA yang dilaksanakan di kelas $X$. Peminatan peserta didik dapat diartikan suatu pembelajaran berbasis minat peserta didik sesuai kesempatan belajar yang ada dalam satuan pendidikan dan suatu proses yang berkesinambungan untuk memfasilitasi peserta didik mencapai keberhasilan proses dan hasil belajar serta perkembangan optimal dalam rangka mencapai tujuan pendidikan nasional [5].

SMA N 1 Purwodadi adalah salah satu SMA Negeri di kota Purwodadi yang telah menerapkan kurikulum 2013. Pelaksanaan penjurusan yang sebelumnya dilakukan di kelas XI, sekarang dilakukan di kelas X. Proses peminatan yang dilakukan oleh guru BK masih menggunakan metode manual, yaitu dengan cara membandingkan nilai siswa yang satu dengan yang lain, sehingga dalam penggunaannya seringkali menghabiskan waktu yang lama. Proses peminatan yang dilakukan secara manual tersebut dinilai kurang efektif dan kurang efisien dalam mengatasi masalah peminatan, maka dibuatlah sebuah sistem pendukung keputusan yang dapat digunakan untuk membantu proses penilaian dengan lebih cepat dan efisien. Metode yang digunakan dalam sistem pendukung keputusan ini adalah Weighted Product.Metode Weighted Product adalah salah satu metode penyelesaian pada masalah MADM.Menurut Yoon, metode Weighted Product menggunakan perkalian untuk menghubungkan rating atribut, dimana rating tiap atribut harus dipangkatkan terlebih dahulu dengan bobot atribut yang bersangkutan. Proses ini sama halnya dengan proses normalisasi [6].Dengan menggunakan metode Weighted Product diharapkan dapat 
memperoleh nilai prioritas dalam sistem pendukung keputusan penentuan peminatan peserta didik pada SMA N 1 Purwodadi.

\section{Tinjauan Pustaka}

\section{Peminatan Peserta Didik}

Peminatan adalah proses yang berkesinambungan, peminatan harus berpijak pada kaidah-kaidah dasar yang secara eksplisit dan implisit, terkandung dalam kurikulum. Peminatan pilihan kelompok mata pelajaran, pilihan lintas mata pelajarandan pilihan pendalaman materi mata pelajaran merupakan upaya untuk membantu peserta didik dalam memilih dan menetapkan mata pelajaran yang diikuti pada satuan pendidikan di SMA, memahami dan memilih arah pengembangan karir, dan menyiapkan diri serta memilih pendidikan lanjutan sampai ke perguruan tinggi sesuai dengan kemampuan dasar umum, bakat, minat dan kecenderungan pilihan masing-masing peserta didik. Peminatan peserta didik dapat diartikan suatu pembelajaran berbasis minat peserta didik sesuai kesempatan belajar yang ada dalam satuan pendidikan dan suatu proses yang berkesinambungan untuk memfasilitasi peserta didik mencapai keberhasilan proses dan hasil belajar serta perkembangan optimal dalam rangka mencapai tujuan pendidikan nasional [5].

\section{Sistem Pendukung Keputusan}

Sistem Pendukung Keputusan (SPK) adalah sistem berbasis komputer yang terdiri dari tiga komponen yang saling berinteraksi, yaitu sistem bahasa (mekanisme untuk memberikan komunikasi antara pengguna dan komponen SPK lain), sistem pengetahuan (repositori pengetahuan domain masalah yang ada pada SPK entah sebagai data atau sebagai prosedur), dan sistem pemrosesan masalah (hubungan antara dua komponen lainnya, terdiri dari satu atau lebih kapabilitas manipulasi masalah umum yang diperlukan untuk pengambilan keputusan)[10].

\section{MultiAttribute Decision Making (MADM)}

Sebagian besar pendekatan MADM dilakukan melalui 2 langkah, yaitu: pertama, melakukan agregasi terhadap keputusan- keputusan yang tanggap terhadap semua tujuan pada setiap alternatif; kedua, melakukan perankingan alternatif-alternatif keputusan tersebut berdasarkan hasil agregasi keputusan. Masalahpengambilan keputusan multi atribut adalah mengevaluasi $m$ alternatif $A_{i}(i=1,2, \ldots, m)$ terhadap sekumpulan atribut atau kriteria $\mathrm{C}_{\mathrm{j}}$ $(\mathrm{j}=1,2, \ldots, \mathrm{n})$, yang setiap atribut saling tidak bergantung satu dengan yang lainnya.

$$
\begin{aligned}
& \mathrm{X}=
\end{aligned}
$$

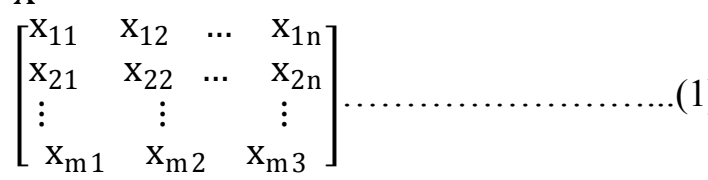

$$
\begin{aligned}
& \mathrm{X}_{\mathrm{ij}} \mathrm{yang} \text { ada dalam persamaan } 1
\end{aligned}
$$
merupakan rating kinerja alternatif ke-i terhadap atribut ke-j.

$\mathrm{W}=\left\{\mathrm{w}_{1}, \mathrm{w}_{2}, \ldots, \mathrm{w}_{\mathrm{n}}\right\}$

W yang ada dalam persamaan 2 merupakan nilai bobot yang menunjukkan tingkat kepentingan relatif setiap atribut.

Rating kinerja (X) dan nilai bobot (W) merupakan nilai utama yang merepresentasikan preferensi absolut dari pengambil keputusan. Masalah pengambilan keputusan multi atribut diakhiri dengan proses perankingan untuk mendapatkan alternatif terbaik yang diperoleh berdasarkan nilai keseluruhan preferensi yang diberikan [6].

\section{Weighted Product (WP)}

Metode WPmenggunakan perkalian untuk menghubungkan rating atribut, dimana rating setiap atribut harus dipangkatkan dulu dengan bobot atribut yang bersangkutan. Proses ini sama halnya dengan proses normalisasi [6].Langkahlangkah dalam perhitungan metode Weighted Product sebagai berikut :

1. Proses Perbaikan Bobot

$$
w_{\mathrm{j}}=\frac{w_{j}}{\sum w_{j}} ; \text { dengan total bobot } \Sigma \mathrm{wj}=1 \ldots
$$

\section{Penentuan Preferensi Vektor S}

$$
S_{i}=\prod_{j}^{n} x_{i j}^{w_{j}} ; \text { dengan } \mathrm{i}=1,2, \ldots, \mathrm{m}
$$


$\mathrm{W}_{\mathrm{j}}$ adalah pangkat bernilai positif untuk atribut keuntungan, dan bernilai negatif untuk atribut biaya.

3. Penentuan Preferensi Vektor V

$$
V_{i}=\frac{\prod_{j}^{n} x_{i j}^{w_{j}}}{\prod_{j}^{n}\left(x_{j}^{*}\right)^{w_{j}}} \quad ; \text { dengan } \mathrm{i}=1,2, \ldots, \mathrm{m}
$$$$
\text { (2.5) }
$$

\section{Implementasi dan Pembahasan}

\section{AnalisisPenentuan Peminatan Peserta Didik}

Kriteria yang digunakan dalam proses penentuan peminatanpeserta didik adalah :

1. Nilai UN

2. Prestasi Non Akademik

3. Psikotes

4. Minat

\section{Analisis Perhitungan}

Contoh data alternatif yang digunakan untuk perhitungan dapat dilihat pada Tabel 1 .

Tabel 1. Contoh Data Alternatif

\begin{tabular}{|c|c|c|c|c|c|c|}
\hline \multirow[b]{2}{*}{ Nama } & \multirow[b]{2}{*}{$\begin{array}{c}\text { Nila } \\
\text { i } \\
\text { UN }\end{array}$} & \multirow[b]{2}{*}{$\begin{array}{c}\text { Presta } \\
\text { si Non } \\
\text { Ak. }\end{array}$} & \multicolumn{2}{|c|}{ Psikotes } & \multicolumn{2}{|c|}{ Minat } \\
\hline & & & $\begin{array}{c}\text { Sko } \\
\mathbf{r} \\
\text { MI } \\
\text { A } \\
\end{array}$ & $\begin{array}{c}\text { Sko } \\
\mathbf{r} \\
\text { IIS }\end{array}$ & I & II \\
\hline Aditya & 9.1 & - & 111 & 110 & MIA & IIS \\
\hline Ardata & 8.1 & 3.00 & 108 & 106 & MIA & IIS \\
\hline Devita & 9.0 & - & 114 & 113 & MIA & IIS \\
\hline Dimas & 8.1 & - & 88 & 89 & MIA & IIS \\
\hline Elma & 8.3 & 3.00 & 101 & 99 & MIA & IIS \\
\hline $\begin{array}{l}\text { Febria } \\
\mathrm{n}\end{array}$ & 8.4 & 3.00 & 89 & 91 & IIS & MIA \\
\hline Fatma & 7.7 & - & 103 & 102 & IIS & MIA \\
\hline Melya & 8.8 & 1.25 & 103 & 101 & MIA & IIS \\
\hline Kiki & 8.7 & - & 112 & 111 & IIS & MIA \\
\hline $\begin{array}{l}\text { Syafir } \\
\text { a }\end{array}$ & 7.4 & & 99 & 100 & IIS & MIA \\
\hline
\end{tabular}

Langkah-langkah penyelesaian masalah penentuan peminatan adalah sebagai berikut :

1. Menentukan matriks keputusan dengan cara mengkonversi data alternatif.Menurut Kusumadewi, rating kecocokan setiap alternatif pada setiap kriteria dinilai dengan 1 sampai 5 [6]. Penentuan rating kecocokan untuk setiap krtiteria dalam peminatan ditentukan oleh pihak sekolah. Tabel rating kecocokan dapat dilihat pada Tabel 2.

Tabel 2. Rating Kecocokan

\begin{tabular}{lrrrrr}
\hline Rating & Bobot & $\begin{array}{c}\text { Nilai } \\
\text { UN }\end{array}$ & $\begin{array}{c}\text { Prestasi } \\
\text { Non } \\
\text { Ak. }\end{array}$ & Psikotes & $\begin{array}{c}\text { Prioritas } \\
\text { Minat }\end{array}$ \\
\hline $\begin{array}{l}\text { Sangat } \\
\text { Baik }\end{array}$ & 5 & $8.6-$ & $4.1-5$ & Terbesar & Minat I \\
Baik & 4 & $7.1-$ & $3.1-4$ & & \\
& & 8.5 & & & \\
Cukup & 3 & $5.6-7$ & $1.6-3$ & Terkecil & Minat II \\
Buruk & 2 & $4.1-$ & $0.5-1.5$ & & \\
& & 5.5 & & & \\
Sangat & 1 & $0-4$ & $0-0.4$ & & \\
Buruk & & & & & \\
\hline
\end{tabular}

Sehingga didapatkan matriks keputusan minat pertama dan minat kedua pada Tabel 3 dan Tabel 4.

Tabel 3. Matriks Keputusan Minat Pertama

\begin{tabular}{lrrrr}
\hline \multirow{2}{*}{ Nama } & \multicolumn{4}{c}{ Kriteria } \\
\cline { 2 - 5 } & C1 & C2 & C3 & C4 \\
\hline Aditya & 5 & 1 & 5 & 5 \\
Ardata & 4 & 3 & 5 & 5 \\
Devita & 5 & 1 & 5 & 5 \\
Dimas & 4 & 1 & 3 & 5 \\
Elma & 4 & 3 & 5 & 5 \\
Febrian & 4 & 3 & 5 & 5 \\
Fatma & 4 & 1 & 3 & 5 \\
Melya & 5 & 2 & 5 & 5 \\
Kiki & 5 & 1 & 3 & 5 \\
Syafira & 4 & 1 & 5 & 5 \\
\hline
\end{tabular}

Tabel 4. Matriks Keputusan Minat Kedua

\begin{tabular}{lrrrr}
\hline \multirow{2}{*}{ Nama } & \multicolumn{4}{c}{ Kriteria } \\
\cline { 2 - 5 } & C1 & C2 & C3 & C4 \\
\hline Aditya & 5 & 1 & 3 & 3 \\
Ardata & 4 & 3 & 3 & 3 \\
Devita & 5 & 1 & 3 & 3 \\
Dimas & 4 & 1 & 5 & 3 \\
Elma & 4 & 3 & 3 & 3 \\
Febrian & 4 & 3 & 3 & 3 \\
Fatma & 4 & 1 & 5 & 3 \\
Melya & 5 & 2 & 3 & 3 \\
Kiki & 5 & 1 & 5 & 3 \\
Syafira & 4 & 1 & 3 & 3 \\
\hline
\end{tabular}

Keterangan :

$\mathrm{C} 1$ = Nilai UN

$\mathrm{C} 2=$ Prestasi Non Akademik

C3 = Nilai Psikotes

$\mathrm{C} 4=$ Minat 
2. Proses perhitungan dengan metode Weighted Product.Tahapan dalam perhitungan metode ini adalah sebagai berikut :

a. Menentukan bobot dan menghitung perbaikan bobot. Penentuan bobot berdasarkan nilai tingkat kepentingan masing-masing kriteria. Menurut Kusumadewi, tingkat kepentingan setiap kriteria dinilai dengan 1 sampai 5 [6]. Tabel tingkat kepentingan dapat dilihat pada Tabel 5.

Tabel 5. Tingkat Kepentingan

\begin{tabular}{|c|c|}
\hline $\begin{array}{c}\text { Tingkat } \\
\text { Kepentingan }\end{array}$ & Nilai \\
\hline Sangat Tinggi & 5 \\
\hline Tinggi & 4 \\
\hline Cukup & 3 \\
\hline Rendah & 2 \\
\hline Sangat Rendah & 1 \\
\hline
\end{tabular}

Nilai bobot atau bobot awal $(W)$ masingmasing kriteria telah ditentukan oleh pihak sekolah pada Tabel 6.

Tabel 6. Bobot dan Nilai Kepentingan

\begin{tabular}{llr}
\hline $\begin{array}{c}\text { Id } \\
\text { Kriteria }\end{array}$ & \multicolumn{1}{c}{ Nama Kriteria } & Nilai \\
\hline C1 & Nilai UN & 5 \\
C2 & Pretsasi Non Akademik & 3 \\
C3 & Nilai Psikotes & 5 \\
C4 & Minat & 4 \\
\hline
\end{tabular}

Kategori setiap kriteria :

- Kriteria C1 (Nilai UN), C2 (Prestasi Non Akademik), C3 (Nilai Psikotes) dan C4 (Minat) adalah kriteria keuntungan.

- Tidak ada kriteria yang termasuk dalam kriteria biaya.

Kemudian dilakukan proses perbaikan bobot $\left(W_{\mathrm{j}}\right)$ terlebih dahulu sehingga total bobot $\Sigma w j=1$. Nilai $W_{1}$ sampai $W_{4}$ dihitung dengan menggunakan persamaan 2.3 dan dihasilkan nilai $W_{1}$ sampai $W_{4}$ sebagai berikut:
$W_{1 \text { (Nilai UN) }}$
$=\frac{5}{5+3+4+5}=$

0.29

$$
\begin{aligned}
& W_{2 \text { (Prestasi Non Akademik) }}=\frac{3}{5+3+4+5}= \\
& 0.18 \\
& W_{3 \text { (Nilai Psikotes) }}=\frac{5}{5+3+4+5}=0.29 \\
& W_{4 \text { (Minat) }} \quad=\frac{4}{5+3+4+5}=0.24
\end{aligned}
$$

b. Menghitung nilai preferensi vektor $S$. Nilai vektor $\mathrm{S}$ dihitung dengan menggunakan persamaan 2.4.

Siswa 1, untuk vektor $\mathrm{S}$ minat $1 \rightarrow \mathrm{S}_{\text {minat } 1}$ $=\left(5^{0.29}\right)\left(1^{0.18}\right)\left(5^{0.29}\right)\left(5^{0.24}\right)=3.764$ untuk vektor $S$ minat $2 \rightarrow S_{\text {minat } 2}$ $=\left(5^{0.29}\right)\left(1^{0.18}\right)\left(3^{0.29}\right)\left(3^{0.24}\right)=$ 2.872

Siswa 2, untuk vektor $\mathrm{S}$ minat $1 \rightarrow \mathrm{S}_{\text {minat } 1}$ $=\left(4^{0.29}\right)\left(3^{0.18}\right)\left(5^{0.29}\right)\left(5^{0.24}\right)=4.279$ untuk vektor $\mathrm{S}$ minat $2 \rightarrow \mathrm{S}_{\text {minat2 }}$ $=\left(4^{0.29}\right)\left(3^{0.18}\right)\left(3^{0.29}\right)\left(3^{0.24}\right)=3.265$

Siswa 3, untuk vektor $\mathrm{S}$ minat $1 \rightarrow \mathrm{S}_{\text {minat1 }}$ $=\left(5^{0.29}\right)\left(1^{0.18}\right)\left(5^{0.29}\right)\left(5^{0.24}\right)=$ 3.764

untuk vektor $\mathrm{S}$ minat $2 \rightarrow \mathrm{S}_{\text {minat2 }}$ $=\left(5^{0.29}\right)\left(1^{0.18}\right)\left(3^{0.29}\right)\left(3^{0.24}\right)=$ 2.872

Siswa 4 , untuk vektor $S$ minat $1 \rightarrow S_{\text {minat1 }}$ $=\left(4^{0.29}\right)\left(1^{0.18}\right)\left(3^{0.29}\right)\left(5^{0.24}\right)=$ 3.033

untuk vektor $\mathrm{S}$ minat $2 \rightarrow \mathrm{S}_{\text {minat2 }}$ $=\left(4^{0.29}\right)\left(1^{0.18}\right)\left(5^{0.29}\right)\left(3^{0.24}\right)=$ 3.126

Siswa 5, untuk vektor $\mathrm{S}$ minat $1 \rightarrow \mathrm{S}_{\text {minat1 }}$ $=\left(4^{0.29}\right)\left(3^{0.18}\right)\left(5^{0.29}\right)\left(5^{0.24}\right)=4.279$ untuk vektor $\mathrm{S}$ minat $2 \rightarrow \mathrm{S}_{\text {minat2 }}$ $=\left(4^{0.29}\right)\left(3^{0.18}\right)\left(3^{0.29}\right)\left(3^{0.24}\right)=3.265$

Siswa 6, untuk vektor $\mathrm{S}$ minat $1 \rightarrow \mathrm{S}_{\text {minat1 }}$ $=\left(4^{0.29}\right)\left(3^{0.18}\right)\left(5^{0.29}\right)\left(5^{0.24}\right)=4.279$ untuk vektor $\mathrm{S}$ minat $2 \rightarrow \mathrm{S}_{\text {minat2 }}$ $=\left(4^{0.29}\right)\left(3^{0.18}\right)\left(3^{0.29}\right)\left(3^{0.24}\right)=3.265$

Siswa 7 , untuk vektor $S$ minat $1 \rightarrow S_{\text {minat } 1}$ $=\left(4^{0.29}\right)\left(1^{0.18}\right)\left(3^{0.29}\right)\left(5^{0.24}\right)=$ 3.033

untuk vektor $\mathrm{S}$ minat $2 \rightarrow \mathrm{S}_{\text {minat2 }}$ $=\left(4^{0.29}\right)\left(1^{0.18}\right)\left(5^{0.29}\right)\left(3^{0.24}\right)=$ 3.126

Siswa 8, untuk vektor $\mathrm{S}$ minat $1 \rightarrow \mathrm{S}_{\text {minat1 }}$ $=\left(5^{0.29}\right)\left(2^{0.18}\right)\left(5^{0.29}\right)\left(5^{0.24}\right)=4.254$ untuk vektor $\mathrm{S}$ minat $2 \rightarrow \mathrm{S}_{\text {minat2 }}$ $=\left(5^{0.29}\right)\left(2^{0.18}\right)\left(3^{0.29}\right)\left(3^{0.24}\right)=3.246$ 
Siswa 9, untuk vektor $S$ minat $1 \rightarrow S_{\text {minat } 1}$ $=\left(5^{0.29}\right)\left(1^{0.18}\right)\left(3^{0.29}\right)\left(5^{0.24}\right)=$ 3.239

untuk vektor $\mathrm{S}$ minat $2 \rightarrow \mathrm{S}_{\text {minat2 }}$ $=\left(5^{0.29}\right)\left(1^{0.18}\right)\left(5^{0.29}\right)\left(3^{0.24}\right)=$ 3.338

Siswa 10, untuk vektor $\mathrm{S}$ minat $1 \rightarrow \mathrm{S}_{\text {minat1 }}$ $=\left(4^{0.29}\right)\left(1^{0.18}\right)\left(5^{0.29}\right)\left(5^{0.24}\right)=$ 3.525

untuk vektor $\mathrm{S}$ minat $2 \rightarrow \mathrm{S}_{\text {minat2 }}$ $=\left(4^{0.29}\right)\left(1^{0.18}\right)\left(3^{0.29}\right)\left(3^{0.24}\right)=$ 2.690

c. Menghitung nilai preferensi vektor V. Nilai vektor $\mathrm{V}$ dihitung dengan menggunakan persamaan 2.5.

Siswa 1, untuk vektor $\mathrm{V}$ minat $1 \rightarrow$ $\mathrm{V}_{\text {minat } 1}=\frac{3.764}{3.764+2.872}=\frac{3.764}{6.636}=$ 0.5672

untuk vektor $\mathrm{V}$ minat $2 \rightarrow$ $\mathrm{V}_{\text {minat2 }}=\frac{2.872}{3.764+2.872}=\frac{2.872}{6.636}=$ 0.4328

Siswa 2, untuk vektor $\mathrm{V}$ minat $1 \rightarrow$ $\mathrm{V}_{\text {minat } 1}=\frac{4.279}{4.279+3.265}=\frac{4.279}{7.544}=$ 0.5672

untuk vektor $\mathrm{V}$ minat $2 \rightarrow$ $\mathrm{V}_{\text {minat2 }}=\frac{3.265}{4.279+3.265}=\frac{3.265}{7.544}=$ 0.4328

Siswa 3, untuk vektor $\mathrm{V}$ minat $1 \rightarrow$ $\mathrm{V}_{\text {minat } 1}=\frac{3.764}{3.764+2.872}=\frac{3.764}{6.636}=$ 0.5672

untuk vektor $\mathrm{V}$ minat $2 \rightarrow$ $\mathrm{V}_{\text {minat2 }}=\frac{2.872}{3.764+2.872}=\frac{2.872}{6.636}=$ 0.4328

Siswa 4, untuk vektor $\mathrm{V}$ minat $1 \rightarrow$ $\mathrm{V}_{\text {minat } 1}=\frac{3.0 .33}{3.033+3.126}=\frac{3.033}{6.159}=$ 0.4925

untuk vektor $\mathrm{V}$ minat $2 \rightarrow$ $\mathrm{V}_{\text {minat2 }}=\frac{3.126}{3.033+3.126}=\frac{3.126}{6.159}=$ 0.5075

Siswa 5, untuk vektor $\mathrm{V}$ minat $1 \rightarrow$ $\mathrm{V}_{\text {minat } 1}=\frac{4.279}{4.279+3.265}=\frac{4.279}{7.544}=$ 0.5672

untuk vektor $\mathrm{V}$ minat $2 \rightarrow$ $\mathrm{V}_{\text {minat } 2}=\frac{3.265}{4.279+3.265}=\frac{3.265}{7.544}=$ 0.4328
Siswa 6, untuk vektor $\mathrm{V}$ minat $1 \rightarrow$ $\mathrm{V}_{\text {minat } 1}=\frac{4.279}{4.279+3.265}=\frac{4.279}{7.544}=$ 0.5672

untuk vektor $\mathrm{V}$ minat $2 \rightarrow$ $\mathrm{V}_{\text {minat2 }}=\frac{3.265}{4.279+3.265}=\frac{3.265}{7.544}=$ 0.4328

Siswa 7, untuk vektor $\mathrm{V}$ minat $1 \rightarrow$ $\mathrm{V}_{\text {minat } 1}=\frac{3.0 .33}{3.033+3.126}=\frac{3.033}{6.159}=$ 0.4925

untuk vektor $\mathrm{V}$ minat $2 \rightarrow$ $\mathrm{V}_{\text {minat } 2}=\frac{3.126}{3.033+3.126}=\frac{3.126}{6.159}=$ 0.5075

Siswa 8, untuk vektor $\mathrm{V}$ minat $1 \rightarrow$ $\mathrm{V}_{\text {minat } 1}=\frac{4.254}{4.254+3.246}=\frac{4.254}{7.499}=$ 0.5672

untuk vektor $\mathrm{V}$ minat $2 \rightarrow$ $\mathrm{V}_{\text {minat } 2}=\frac{3.246}{4.254+3.246}=\frac{3.246}{7.499}=$ 0.4328

Siswa 9, untuk vektor $\mathrm{V}$ minat $1 \rightarrow$ $\mathrm{V}_{\text {minat } 1}=\frac{3.239}{3.239+3.338}=\frac{3.239}{6.576}=$ 0.4925

untuk vektor $\mathrm{V}$ minat $2 \rightarrow$ $\mathrm{V}_{\text {minat } 2}=\frac{3.338}{3.239+3.338}=\frac{3.338}{6.576}=$ 0.5075

Siswa 10, untuk vektor $\mathrm{V}$ minat 1 $\rightarrow \mathrm{V}_{\text {minat } 1}=\frac{3.525}{3.525+2.690}=\frac{3.525}{6.215}=$ 0.5672

untuk vektor $\mathrm{V}$ minat $2 \rightarrow$ $\mathrm{V}_{\text {minat } 2}=\frac{2.690}{3.525+2.690}=\frac{2.690}{6.215}=$ 0.4328

Hasil penentuan peminatan siswa didasarkan atas hasil perhitungan dengan metode Weighted Product minat pertama dan minat kedua.Jika hasil dari minat pertama lebih besar dibandingkan dengan minat kedua, maka siswa tersebut disarankan untuk masuk ke dalam minat pertama.Jika hasil dari minat kedua lebih besar dibandingkan dengan minat pertama, maka siswa tersebut disarankan untuk masuk ke dalam minat kedua.Hasil penentuan peminatan dapat dilihat pada Tabel 7. 
Tabel 7. Hasil Penentuan Peminatan Siswa

\begin{tabular}{llllll}
\hline Nama & $\begin{array}{c}\text { Minat } \\
\text { I }\end{array}$ & $\begin{array}{c}\text { Minat } \\
\text { II }\end{array}$ & $\begin{array}{c}\text { Vektor } \\
\mathbf{V}_{\text {minat1 }}\end{array}$ & $\begin{array}{c}\text { Vektor } \\
\mathbf{V}_{\text {minat2 }}\end{array}$ & $\begin{array}{c}\text { Hasil } \\
\text { Minat }\end{array}$ \\
\hline Aditya & MIA & IIS & 0.5672 & 0.4328 & MIA \\
Ardata & MIA & IIS & 0.5672 & 0.4328 & MIA \\
Devita & MIA & IIS & 0.5672 & 0.4328 & MIA \\
Dimas & MIA & IIS & 0.4925 & 0.5075 & IIS \\
Elma & MIA & IIS & 0.5672 & 0.4328 & MIA \\
Febrian & IIS & MIA & 0.5672 & 0.4328 & IIS \\
Fatma & IIS & MIA & 0.4925 & 0.5075 & MIA \\
Melya & MIA & IIS & 0.5672 & 0.4328 & MIA \\
Kiki & IIS & MIA & 0.4925 & 0.5075 & MIA \\
Syafira & IIS & MIA & 0.5672 & 0.4328 & IIS \\
\hline & & & & &
\end{tabular}

\section{Antarmuka}

Antarmuka pada SPK Penentuan Peminatan Peserta DidikMenggunakan Metode Weighted Productmemiliki 11 antarmuka yaitu Index, Input Data Registrasi, Pengumuman Peminatan, Beranda SPK, Input Periode Minat, Validasi Data Siswa, Input Nilai Psikotes, Input Bobot Kriteria, Hasil Perhitungan, Hasil Perbandingan, Hasil Evaluasi Format PDF, dan Pengaturan Akun.

\section{Antarmuka Index}

Halaman ini adalah antarmuka awal sistem.HalamanIndex dapat dilihat pada Gambar 1.

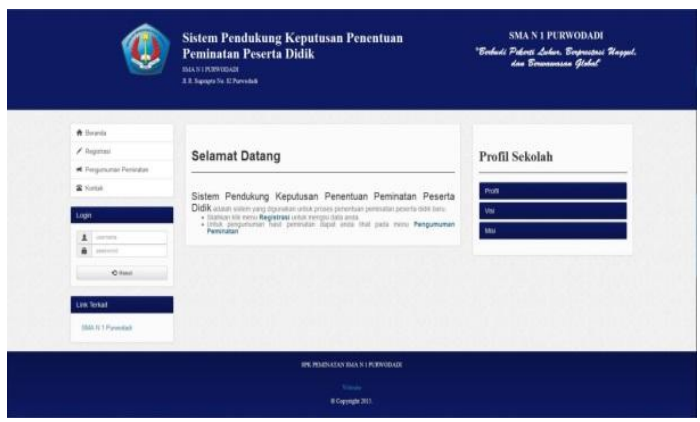

Gambar 1.Halaman Index

2. Antarmuka Input Data Registrasi

Antarmuka halaman Input Data Registrasi digunakan oleh Siswa untuk melakukan proses mendaftar. Halaman Input Data Registrasi dapat dilihat pada Gambar 2.

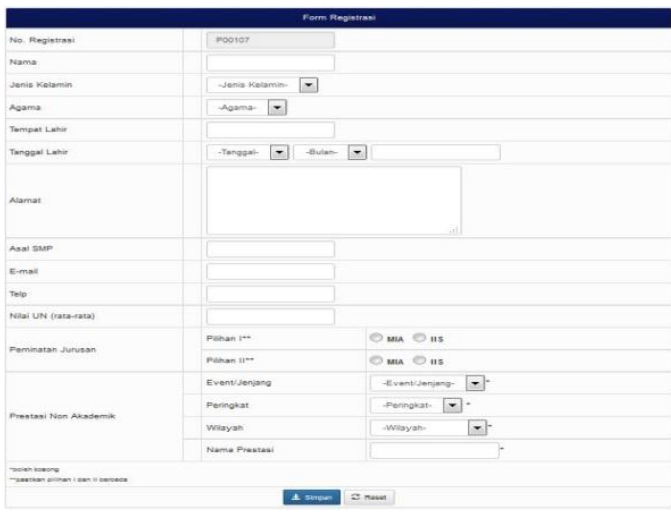

Gambar 2.Halaman Input Data Registrasi

3. Antarmuka Pengumuman Peminatan

Antarmuka halaman Pengumuman Peminatan digunakan oleh Siswa untuk melihat hasil peminatan.Halaman Pengumuman Peminatan dapat dilihat pada Gambar 3.

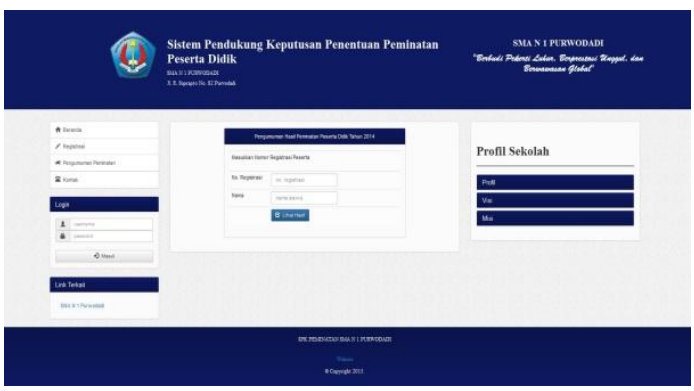

Gambar 3.Halaman Pengumuman Peminatan

4. Antarmuka Beranda SPK

Antarmuka Beranda SPK adalah halaman awal untuk pengguna Guru BK dalam penentuan peminatan.Halaman Beranda SPK dapat dilihat pada Gambar 4.

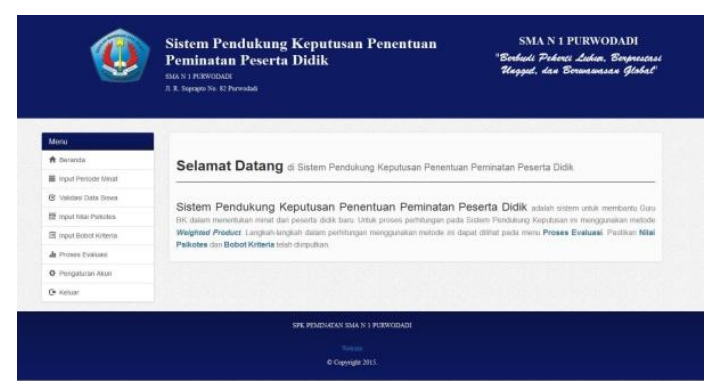

Gambar 4.Halaman Beranda SPK

5. Antarmuka Input Periode Minat

Antarmuka halaman Input Periode Minat digunakan oleh Guru BK untuk memasukkan 
data periode peminatan.Halaman Input Periode Minat dapat dilihat pada Gambar 5.

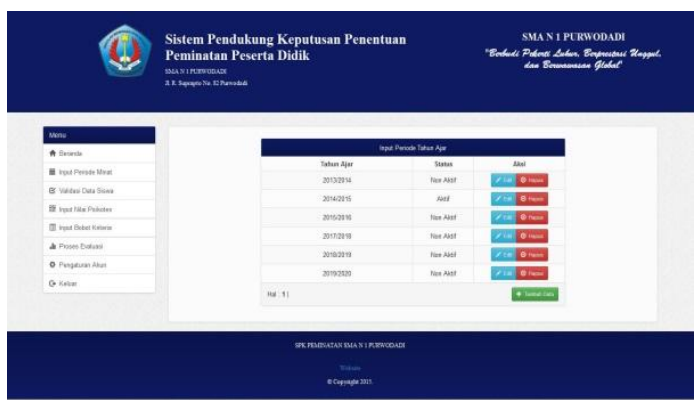

Gambar 5.Halaman Input Periode Minat

6. Antarmuka Validasi Data Siswa

Antarmuka halaman Validasi Data Siswa digunakan oleh Guru BK untuk memvalidasi data siswa yang telah mendaftar.Halaman Validasi Data Siswa dapat dilihat pada Gambar 6.

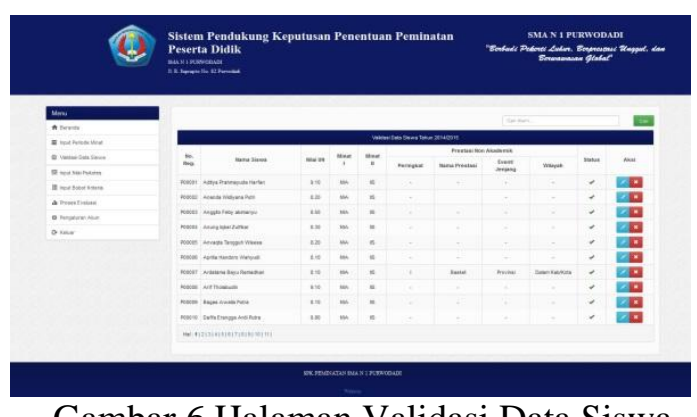

Gambar 6.Halaman Validasi Data Siswa

7. Antarmuka Input Nilai Psikotes

Antarmuka halaman Input Nilai Psikotes digunakan oleh Guru BK untuk memasukkan nilai psikotes.Halaman Input Nilai Psikotes dapat dilihat pada Gambar 7.

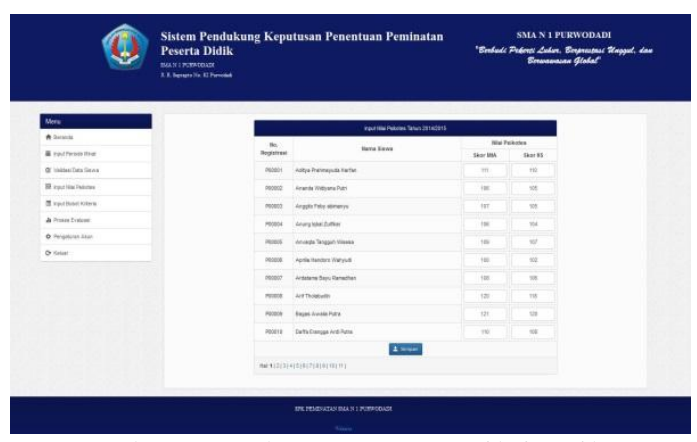

Gambar 7.Halaman Input Nilai Psikotes
8. Antarmuka Input Bobot Kriteria Antarmuka halaman Input Bobot Kriteria digunakan oleh Guru BK untuk memasukkan nilai bobot dari setiap kriteria.Halaman Input Bobot Kriteria dapat dilihat pada Gambar 8.

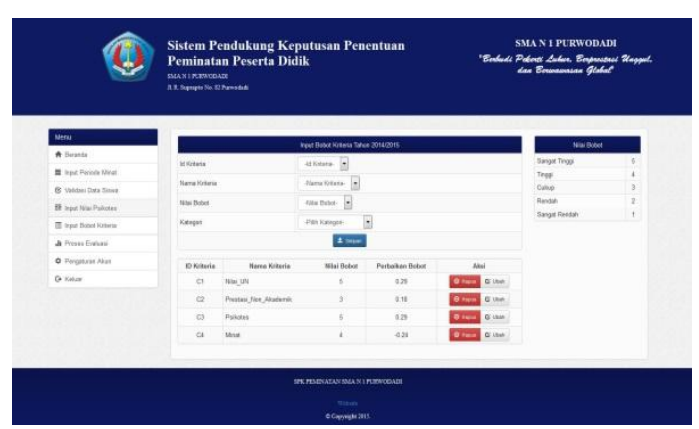

Gambar 8.Halaman Input Bobot Kriteria

9. Antarmuka Hasil Perhitungan

Antarmuka halaman Hasil Perhitungan digunakan oleh Guru BK untuk melihat nilai matriks keputusan, preferensi vektor s dan preferensi vektor v. Halaman Hasil Perhitungan dapat dilihat pada Gambar 9.

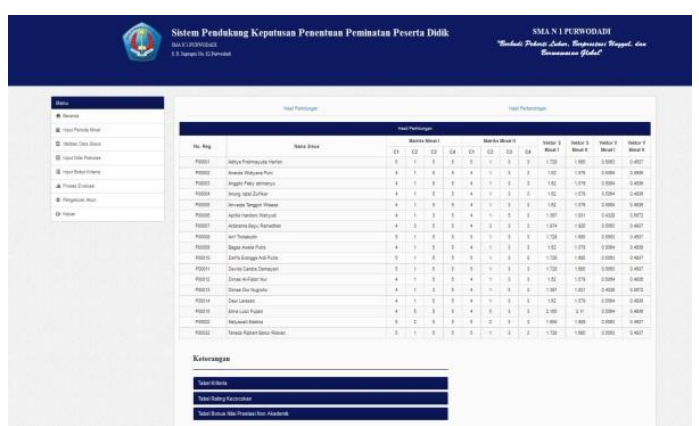

Gambar 9.Halaman Hasil Perhitungan

10. Antarmuka Hasil Perbandingan Antarmuka halaman ini digunakan oleh Guru BK untuk melihat hasil perbandingan minat pertama dan minat kedua.Halaman Hasil Perbandingan dapat dilihat pada Gambar 10. 


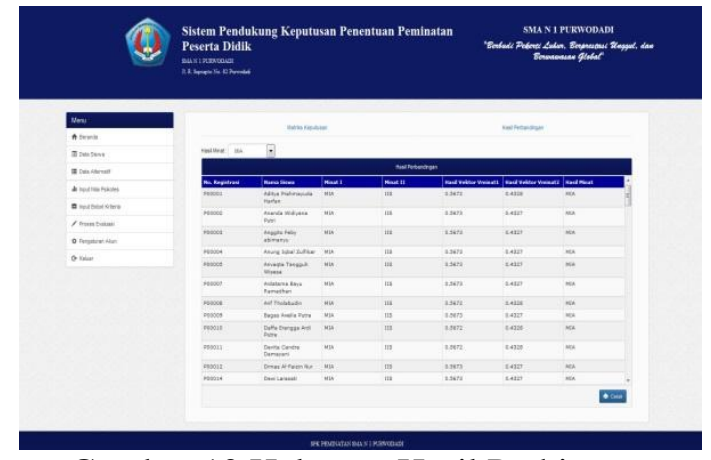

Gambar 10.Halaman Hasil Perhitungan
11. Antarmuka Hasil Evaluasi Format PDF

Antarmuka halaman Hasil Evaluasi Format PDF digunakan oleh Guru BK untuk mencetak hasil evaluasi penentuan peminatan.Halaman Hasil Evaluasi Format PDF dapat dilihat pada Gambar 11.

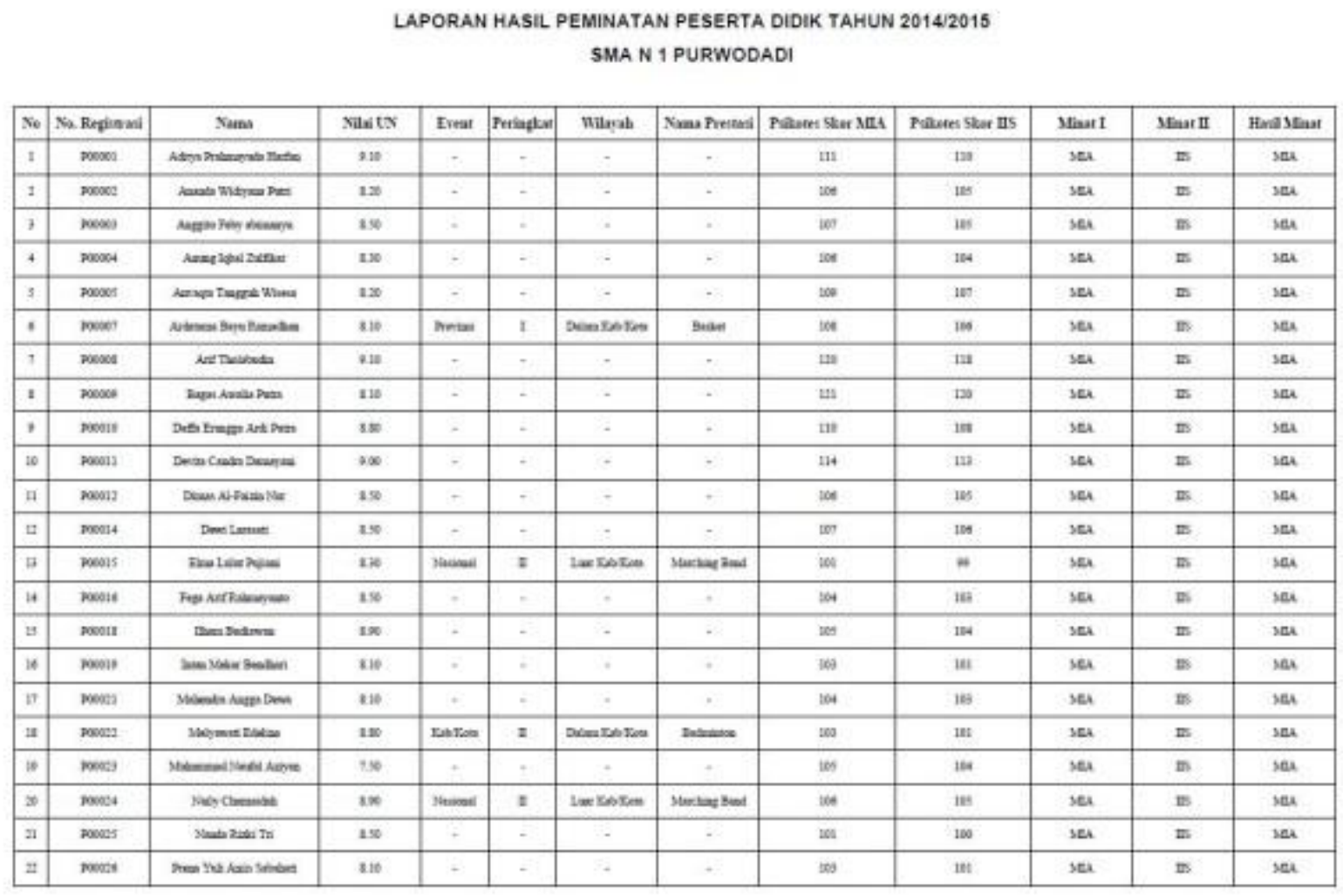

Gambar 11.Halaman Hasil Evaluasi Format PDF

12. Antarmuka Pengaturan Akun

Antarmuka halaman Pengaturan Akun digunakan oleh Guru BK untuk mengubah data akun.Halaman Pengaturan Akun dapat dilihat pada Gambar 12.

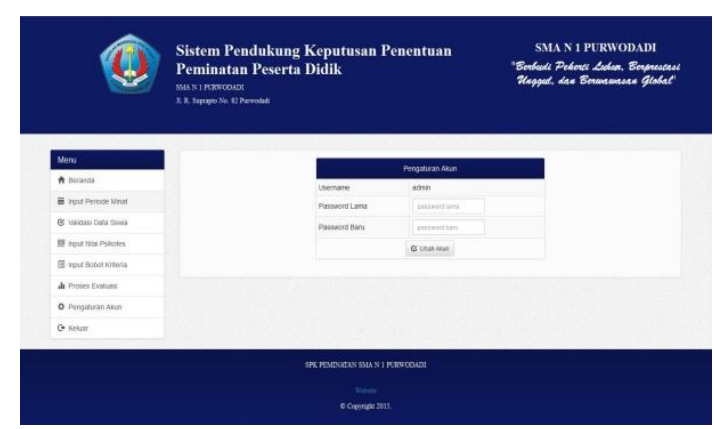

Gambar 12.Halaman Pengaturan Akun 


\section{Kesimpulan}

Sistem Pendukung Keputusan Penentuan Peminatan Peserta Didik Menggunakan Metode Weighted Product dapat dijadikan metode penentuan peminatan sekolah karena dari hasil pengujian dengan membandingkan peminatan secara manual menghasilkan tingkat akurasi sebesar $85 \%$, sehingga dapat membantu pihak sekolah dalam menentukan peminatan dengan lebih efektif dan efisien.Saran yang dapat dilaksanakan untuk pengembangan Sistem Pendukung Keputusan Penentuan Peminatan Peserta Didik Menggunakan Metode Weighted Product lebih lanjut yaitu Sistem dapat dikembangkan dengan menggunakan metode yang berbeda atau mengkombinasikan metode Weighted Product dengan metode lain dan perlu adanya penambahan kriteria sehingga dalam penilaiannya agar lebih optimal.

\section{Referensi}

[1] Al-Bahra. (2005). Analisis dan Desain Sistem Informasi. Yogyakarta: Graha Ilmu.
[2] Community, e. (2011). Indeks Lengkap Syntax. Yogyakarta: MediaKom.

[3] Depdikbud. (2014). Penerimaan Peserta Didik Baru. Grobogan.

[4] Jogiyanto. (2005). Analisis \& Desain Sistem Informasi. Yogyakarta: Andi.

[5] Kemendikbud. (2013). Pedoman Peminatan Peserta Didik. Jakarta.

[6] Kusumadewi, S., Hartati, S., Harjoko, A., \& Wardoyo, R. (2006). Fuzzy Multy Attribute Decision Making (FUZZY MADM). Yogyakarta: Graha Ilmu.

[7] Madcoms. (2010). Kupas Tuntas Adobe Dreamweaver CS5 dengan Pemrograman $P H P \& M y S Q L$. Madiun: Andi.

[8] Pressman, R. S. (2002). Software Engineering : A Practitioner's Approach 5th Edition (Rekayasa Perangkat Lunak: pendekatan praktisi). Yogyakarta: Andi.

[9] Sommerville, I. (2003). Software Engineering. Jakarta: Erlangga.

[10] Turban, E., Aronson, J. E., \& Liang, T.-P. (2005). Decision Support Systems and Intelligent Systems. Yogyakarta: Andi. 
Sistem Pendukung Keputusan Penentuan Peminatan Peserta Didik 